\title{
Households Drinking Water Sources and Treatment Methods Options in a Regional Irrigation Scheme
}

\author{
Emmy C. Kerich ${ }^{1 *}$ \\ ${ }^{1}$ Direcorate of Research and Innovation, University of Eldoret, P.O. BOX 1125, Eldoret, Kenya
}

Received 07 January 2020; Revised 19 February 2020; Accepted 26 February 2020; Published 01 March 2020

\begin{abstract}
Access to safe and clean drinking water is a major challenge for the people living around the Ahero Irrigation Scheme (AIS), Kenya. Water sources in the area are constantly and increasingly polluted by agrochemicals like pesticides from rice farming. 2,4-Dichlorophenoxyacetic acid $(2,4-\mathrm{D})$ is an herbicide extensively used in AIS. The neurotoxic, immunosuppressive, cytotoxic, and hepatoxic effects of $(2,4-\mathrm{D})$ have been well documented. Residues of $(2,4-\mathrm{D})$ have been documented in ponds, rivers, lakes and irrigation canals. Therefore, this study surveyed agrochemicals used in AIS, the drinking water source for the residents, and finally, the water treatment option for the obtained water in the year 2013. The study established that $(52.8 \%)$ of the farmers used hand-weeding and $20.8 \%$ of them used $(2,4-\mathrm{D})$ for weed control. According to the findings, the most preferred water source was lined improved well (47.2\%), followed by irrigation canal $(22.2 \%)$, and rain water $(2.8 \%)$. The most commonly used method of water treatment was chlorination (45.8\%). Spearman's coefficient of correlation $\left(r_{s}\right)$ revealed that there was a positive correlation between the two variables $\left(r_{s}=0.145,72, \mathrm{p}=0.224>0.05\right)$. As $r_{s}$ is positive, it implies that the type of treatment given to water depends on the source of the water. Despite the use of chlorinate by almost half of the residents, some of them (22.2\%) do not treat their water at all, which may pose a risk of getting water-related diseases. Furthermore, despite a proportional number of residents obtaining their water from irrigation canals, all of them do not have an appropriate method/s for treating water contaminated with organic pollutants such as herbicides. There is a need to promote appropriate drinking water treatment $\mathrm{method} / \mathrm{s}$ in the study area to prevent water-related diseases at the family level.
\end{abstract}

Keywords: Drinking Water; Ahero Irrigation Scheme; 2,4-D; Water Sources; Water Treatment Methods.

\section{Introduction}

Water is a major component of the environment and, consequently, is the most vital natural reserve which is crucial for life [1, 2]. A safe, reliable, affordable, and easily accessible water supply is essential for good health [3, 4]. Yet, globally, 2.2 billion people lack access to safe drinking water due to water pollution [5]. Adverse agricultural activities are cited as the leading cause of surface and groundwater pollution [6, 7]. Pollutants such as agrochemicals are some of the most toxic contaminants to human health, fauna, and the environment [8-10]. Agrochemicals refer to various chemical compounds that are used in agriculture. It encompasses insecticides, herbicides, and fungicides; also raw animal manure, synthetic fertilizers, hormones, among others $[11,12]$.

* Corresponding author: emmycheptoo@gmail.com

doi http://dx.doi.org/10. 28991/HEF-2020-01-01-02

$>$ This is an open access article under the CC-BY license (https://creativecommons.org/licenses/by/4.0/).

(c) Authors retain all copyrights. 
2,4-Dichlorophenoxyacetic acid (2,4-D) is the most commonly used pesticide in the Ahero Irrigation Scheme (AIS) and it is a selective herbicide with the highest toxicity to broadleaf plants [13, 14]. It is used for post-emergence control of annual and perennial broad-leaved weeds in cereals, maize, sorghum, rice, and grassland as well as for control of aquatic weeds [15]. In plants, it functions by maintaining high levels of plant hormones like auxine, resulting in overstimulation of plant growth and ultimately death. It also increases ethylene production and therefore acts as a defoliating agent [16-18]. Residues of 2,4-D can enter ponds and streams by direct application or accidental drift; by inflow of herbicide previously deposited in dry stream-bed, pond bottom or irrigation canals; run-off from soil or leaching through the soil column [19, 20]. Only a small fraction of applied pesticides affect the target organisms, and the rest often remains in the soil, contaminates surface water and groundwater resources, or mixes with the air $[21,22]$. Its production and degradation lead to the creation of many compounds that exert strong toxicity [23, 24]. 2,4-D has been linked to several forms of cancer, primarily lymphoma and non-Hodgkins lymphoma, as well as tumors of the lungs, liver, kidney, and brain in humans [14, 25-27].

Irrigation practices play a major role in the accumulation of pesticide residues encountered in water resources, and extensive use of pesticides may pose serious concerns about health risks arising from the contact of farmers when mixing and applying pesticides or working in treated fields and from residues in food and in drinking water for the universal population [28, 29]. Therefore, this paper aims to survey agrochemicals used in AIS, the drinking water source for the residents, and finally, the water treatment option for the obtained water in the year 2013.

\section{Methodology}

\subsection{Study Area}

The Ahero Irrigation Scheme (AIS), Kenya is situated in the Kano plains between the Nandi Escarpment and Nyabondo Plateau in Kisumu County (Figure 1). Construction of the scheme started in 1966 and operations started in 1969 [30]. The scheme is managed by the National Irrigation Board in partnership with the farmers, who are charged Kshs.3100 per acre per year for scheme Operation and Maintenance (O\&M). The area under cultivation is 2168 acres, which is divided into 12 blocks with a total of 1650 farmers. Nearly all irrigated farmland is used for paddy cultivation $[31,32]$. The area has a relatively high humidity of $65 \%$ due to its proximity to Lake Victoria. Local climate is characterized by three peaks of rains with an average annual rainfall of 1,000-1,800 mm and yearly mean temperatures vary between $17^{\circ} \mathrm{C}$ and $32^{\circ} \mathrm{C}$ [33]. The main economic activities include farming and subsistence farming of cultivated maize, sorghum, cassava, millet, and vegetables. Most people keep animals, including cattle, goats, sheep, and poultry. Other activities include fishing due to its proximity to Lake Victoria and the Nyando River $[30,33]$. The Nyando River is the major water source for the people living around the scheme. During the rice planting season, some residences obtain their water for domestic use from the irrigation canals of the scheme.

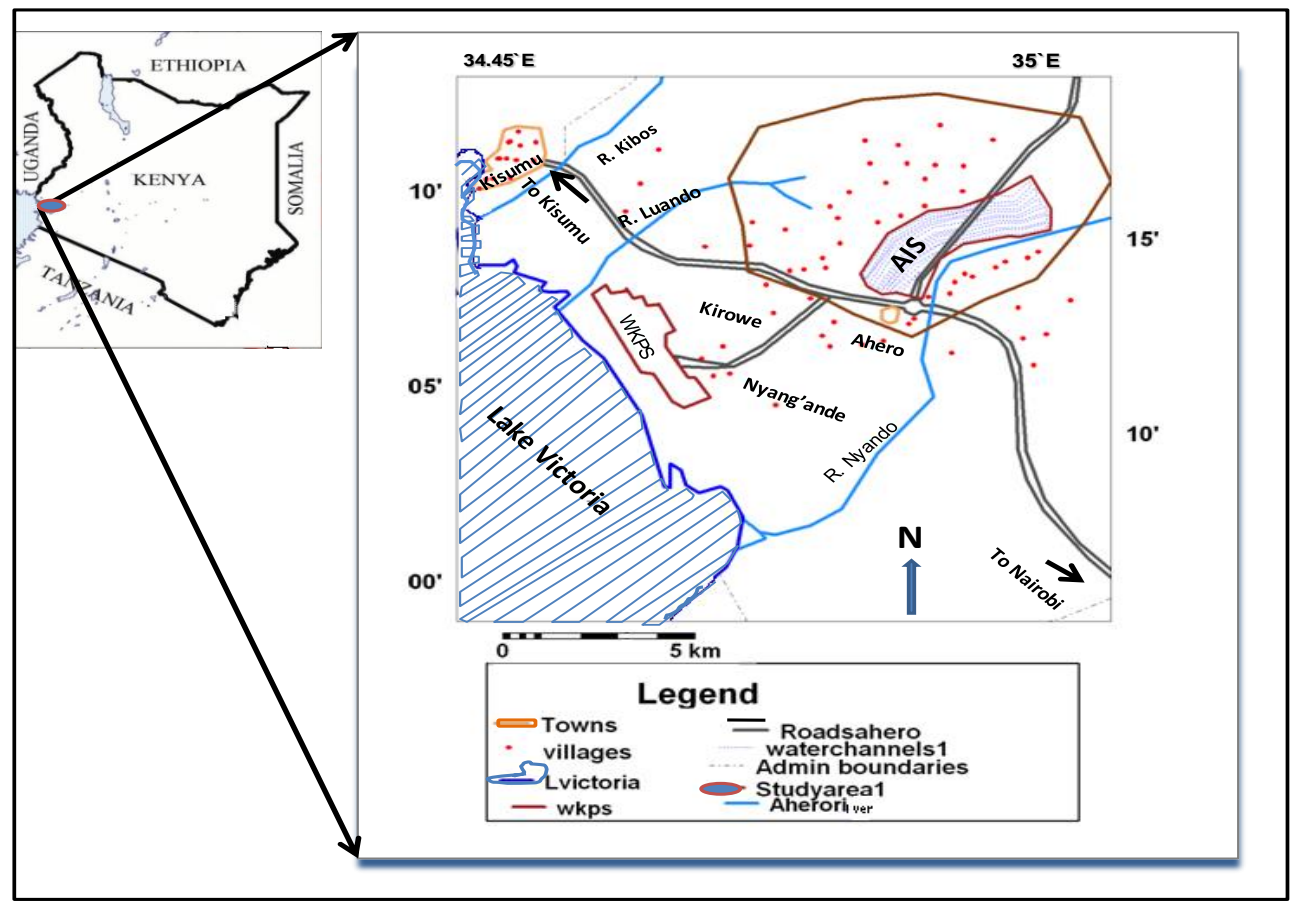

Figure 1. Location Map of Ahero Irrigation Scheme, Kenya 
Rice farming is the main cash crop in the region and it covers approximately 2404 hectares. The residents' main source of water for domestic water are both surface water and groundwater through Nyando River, boreholes, few ponds and irrigation canals during rice planting season. In AIS, rice planting is done throughout the year but in rotation (spatial) due to scarcity of water from Nyando River.

\subsection{Primary Data Collection}

Interviews were conducted and structured questionnaires were administered to stakeholders (Agro-chemist stockiest, National Irrigation Board and local people). All the entire agrochemical stockiest were interviewed while participants from the local community were selected using systematic sampling [34]. The research assistants were trained on how to administer the questionnaires correctly. It consists of selecting the first house along the road and/or path from the irrigation scheme as the first participant and after that every $10^{\text {th }}$ house was interviewed. Data collection was obtained from 72 households living within Ahero irrigation scheme.

\subsection{Sample Size}

The sample size was calculated using a formula proposed by previous studies, which states that:

$$
n=\frac{N}{1+N(e)^{2}}
$$

Where: $\mathrm{n}=$ sample size;

$N=$ target population size;

$e=$ level of precision (sample error);

Therefore, $\mathrm{N}=89$ stakeholders and $\mathrm{e}=5 \%$ :

$$
n=\frac{89}{1+89(0.05)^{2}} \quad \rightarrow \quad n=\frac{89}{1.2225} \rightarrow N=72
$$

The returned questionnaires were validated through focused group discussion in Ahero Irrigation Scheme. The obtained information was used to give the data on the types, amount of the pesticide used around the scheme and also to identify the water sources. The farmers' questionnaires were translated into local dialect for better understanding. The agrochemical stockiest and NIB questionnaires consisted of questions on the type of pesticide and the amount applied per acre.

\subsection{Secondary data collection}

Secondary information was obtained from National Irrigation Board, ministry of water and agriculture. All these institutions availed information from their reports on the soil type or texture, topography of the area, population, vegetation cover, and crops planted.

\subsection{Data Analysis}

Each set of questionnaires, the responses from the farmers, stockiest and NIB were coded and keyed in the statistical package of social scientist (SPSS) to analyze data. Spearman's rank order correlation ( $r_{s}$ ) was used to show whether and how strongly pairs of variables were related where $r_{s}$ value varies between -1 and $1\left(-1 \leq r_{s} \geq 1\right)$.

\section{Results and Discussion}

\subsection{Socio-economic Characteristics of Households}

The general information about socio-economic characteristics of household heads determined were as follows: gender, education level and the length lived in the scheme. The gender distribution of the household is given in Table 1. The level of education is presented in Table 2 and the length of period lived is presented in Table 3.

Table 1. Sex of household head

\begin{tabular}{ccc}
\hline Gender & Frequency & Percentage \\
\hline Female & 49 & 68.1 \\
\hline Male & 23 & 31.9 \\
\hline Total & 72 & 100 \\
\hline
\end{tabular}


Slightly more than two thirds $(68.1 \%)$ of the interviewed household were female compared to close to a third $(31.9 \%)$ who were male.

Among household heads interviewed, $75.0 \%$ attained primary school level, $16.7 \%$ secondary school level, $4.2 \%$ tertiary college $2.8 \%$ university and only $1.4 \%$ vocational/village polytechnic. Three quarter (75\%) attained primary level maybe due to poverty and early marriages Table 2 .

Table 2. Level of education of household heads

\begin{tabular}{ccc}
\hline Level of education & Frequency & Percent \\
\hline Primary & 54 & 75.0 \\
Secondary & 12 & 16.7 \\
Vocational/Village polytechnic & 1 & 1.4 \\
Tertiary College & 3 & 4.2 \\
University & 2 & 2.8 \\
\hline Total & $\mathbf{7 2}$ & $\mathbf{1 0 0 . 0}$ \\
\hline
\end{tabular}

Majority of the household $87.5 \%$ have lived around the scheme at the time of the project more than two years, $8.3 \%$ less than six months, $2.8 \%$ between one to two years, while $1.4 \%$ between six months to one year. The results indicate that majority of the household are permanent residents of Ahero Table 3.

Table 3. Length of time the household head have lived around the Ahero irrigation scheme

\begin{tabular}{ccc}
\hline Time & Frequency & Percent \\
\hline Less than 6 months & 6 & 8.3 \\
6 months to 1 year & 1 & 1.4 \\
1 to 2 years & 2 & 2.8 \\
More than 2 years & 63 & 87.5 \\
\hline Total & 72 & 100 \\
\hline
\end{tabular}

\subsection{Pesticides Application in Ahero Irrigation Scheme}

This study established that $(52.8 \%)$ of the farmers used hand-weeding and $20.8 \%$ of them use $2,4-\mathrm{D}$ for the weeds control (Figure 2). Slightly more than half $(52.8 \%)$ of the farmers use mechanical method of weeding and the remaining $47.2 \%$ use various chemicals.

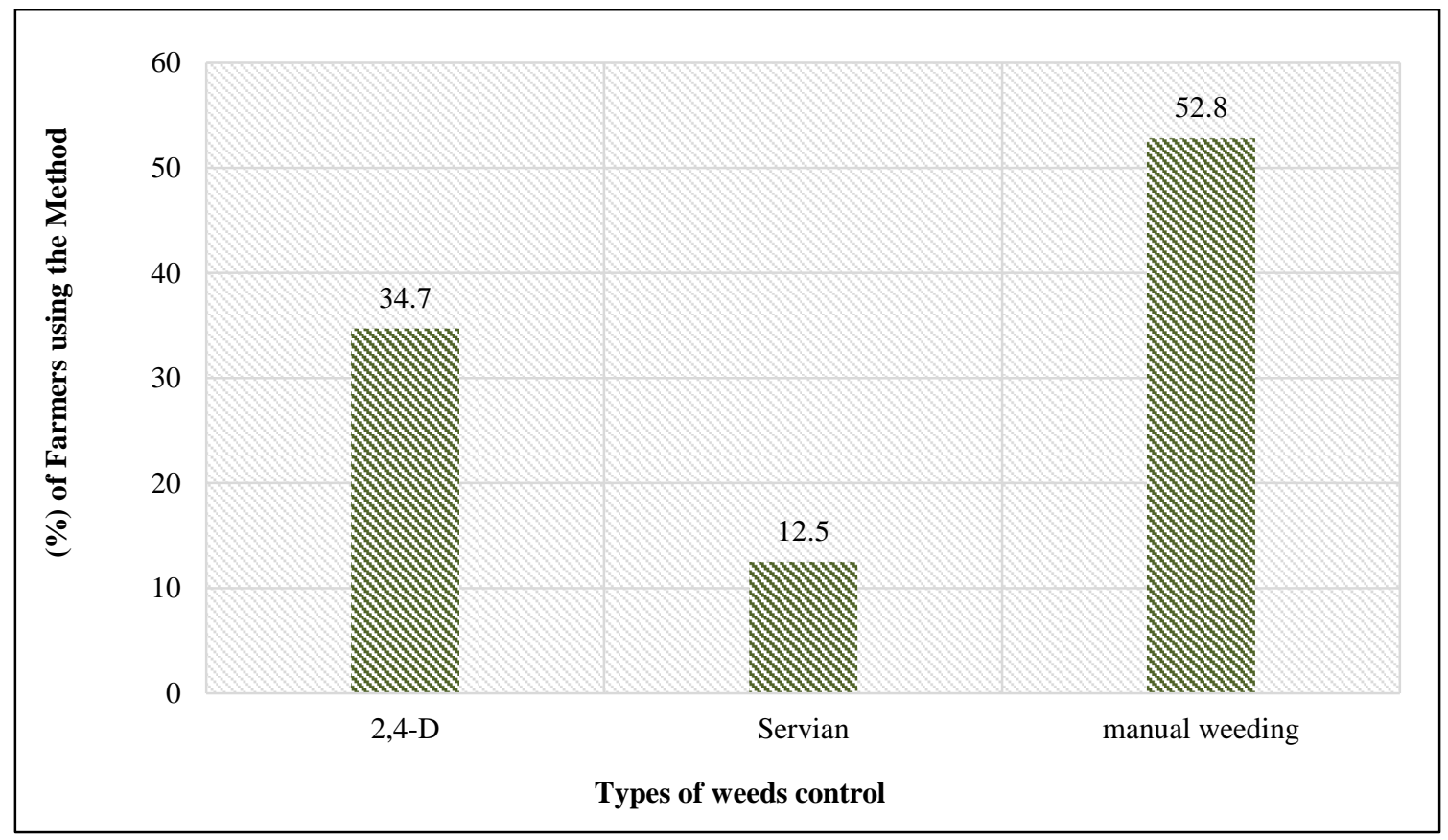

Figure 2. Weed control method used by rice farmers in Ahero irrigation scheme 
It was establish that $20.8 \%$ of the farmers applied 2, $4 \mathrm{D}$ herbicide, $12.5 \%$ of the farmers used Sevian while $8.3 \%$ of the farmers used Di-amine. Murhamine and Dicopur were used by $5.6 \%$ of the farmers. All there herbicides, were applied with the sticker, wetter or sprayer with 0.5 liters of water to enhance efficiency of herbicides to the rice. In MWEA Irrigation Scheme [35] reported about 95\% of the respondents using herbicides for weed control. Out of these, about 54\% used glyphosate while 31\% applied 2,4-D. Rodenburg et al., (2019) noted that 34\% of the rice farmers in Sub- Sahara Africa used herbicides for weeding and majority used hand weeding. Mattah et al. (2015) [36] recorded $35 \%$ of the respondents used round-up (glyphosate $41 \%$ ), while $8.3 \%$ used gramoxone (paraquat) for controlling weeds in the catchment of Ashaiman irrigation scheme of Ghana. From this study, majority of the farmers used handweeding, however for those who used different types of herbicides its impact on household water cannot be underestimated. Health effects linked with pesticide use have been well documented by researchers [37-39].

\subsection{Domestic Water Sources}

The respondents were asked the source of water for their household and the results are given in Figure 3. The results showed that $47.2 \%$ of the people living around Ahero irrigation scheme draws their water for drinking and domestic needs from lined improved well, 22.2\% from irrigation canal, 16.7\% from Nyando River, $4.2 \%$ for open well dug in river bed/wetland and tap water respectively, $2.2 \%$ from pump bore and rain water reservoir respectively.

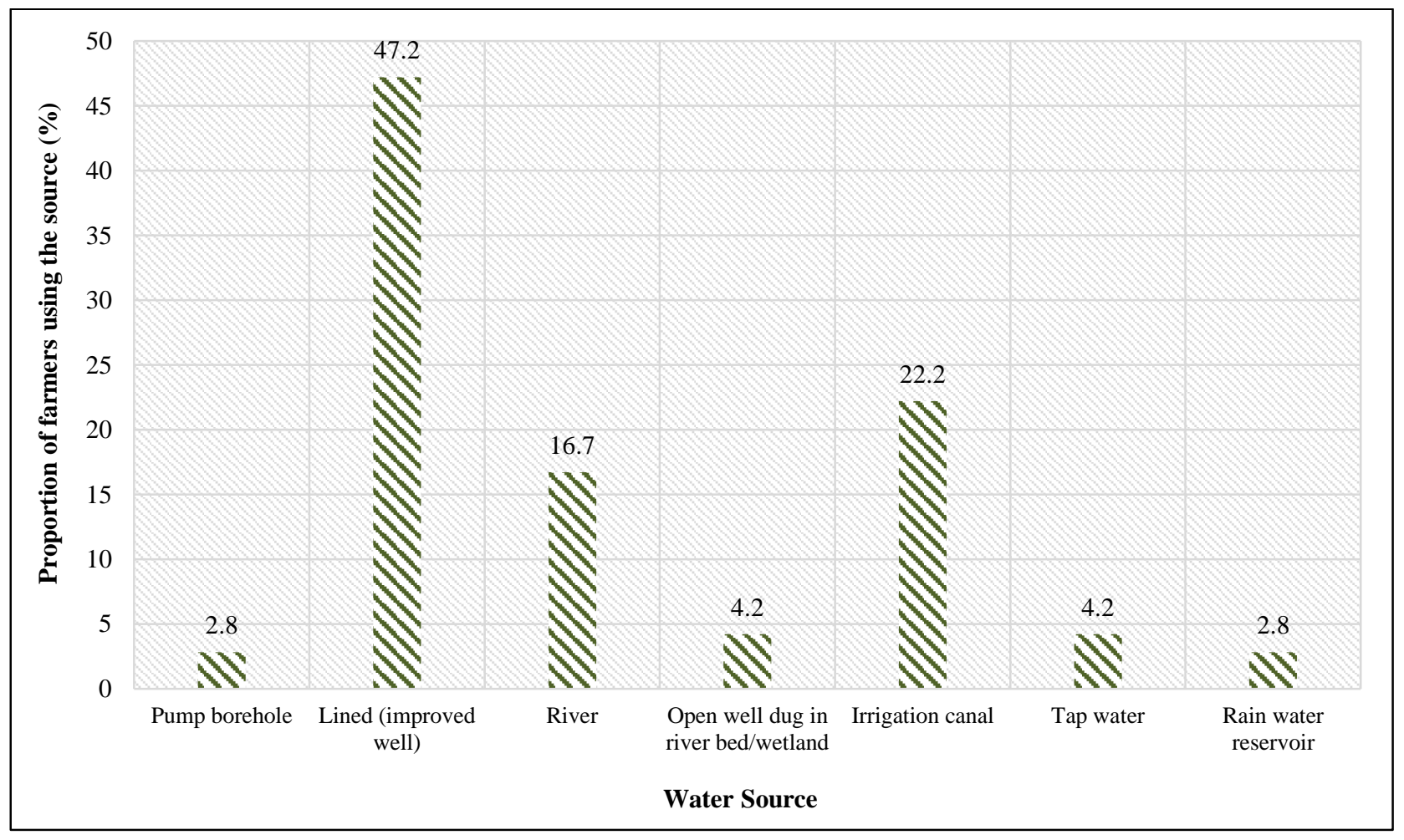

Figure 3. Source of water at the community level

The results indicated that a significant number of household draw their water supply from irrigation canal (22.2\%) and sixteen percent from River Nyando which has a high potential of contamination from agricultural runoff, with pesticides residues (Figure 4). Kanoti et al. [40] reported Lake Victoria, shallow wells, unprotected springs, boreholes and roof catchment systems as a source of water for Kisumu City residents, while evaluating appropriate water treatment for the Nyanza Province of Kenya reported lake, spring, borehole, rivers, ponds, tap and rain water as the sources of water for domestic use [41]. Kiosks and wells/boreholes serve as the primary source for $25.8 \%$ of the households living in Kisumu municipality, Kenya according to Wagah et al. [42]. Wambu et al. (2014) on the other hand reported that majority of the residents of Bondo-Rarieda Area used water from Lake Victoria (37.4\%) and the other preferred dams, open pans, boreholes and streams [43].

Further when respondent were asked on the preference of the water source their results in (Figure 5) shows that $37.5 \%$ of the people living around the scheme prefer water from lined improved well, slightly more than a third (36.1\%) from irrigation canal $18.1 \%$ from the river, $4.2 \%$ from tap water, $2.8 \%$ pump borehole and $1.4 \%$ open well dug in riverbed/wetland. 


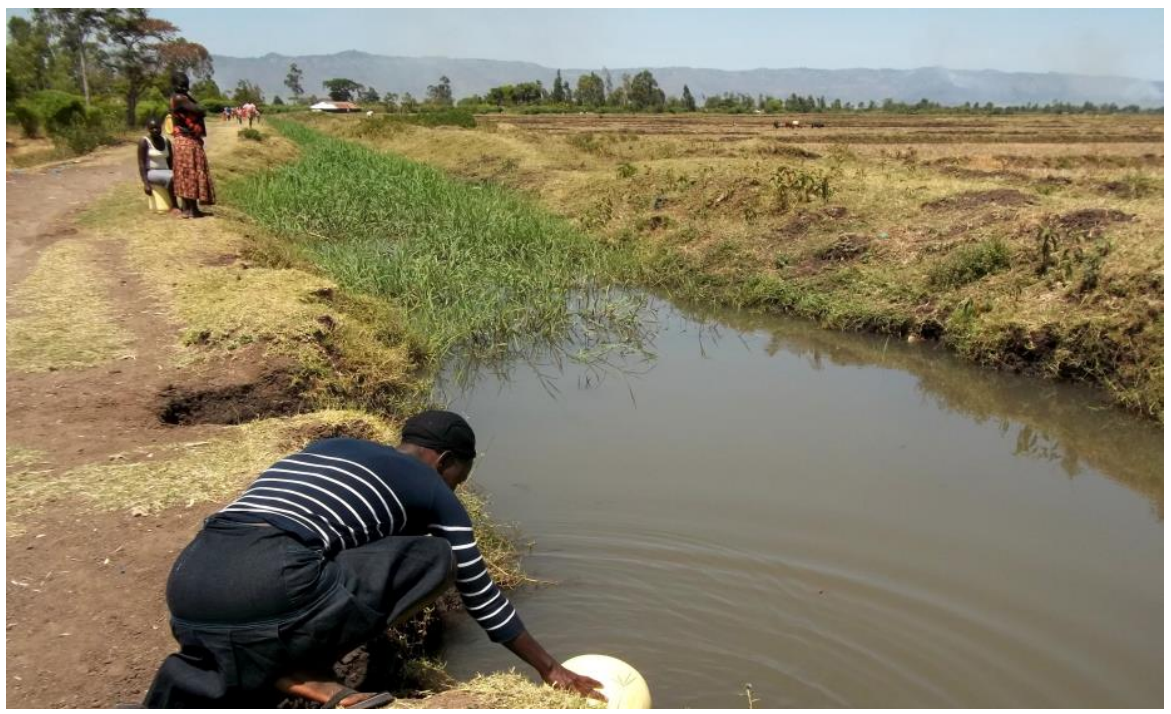

Figure 4. Woman fetching water from irrigation canal for domestic use

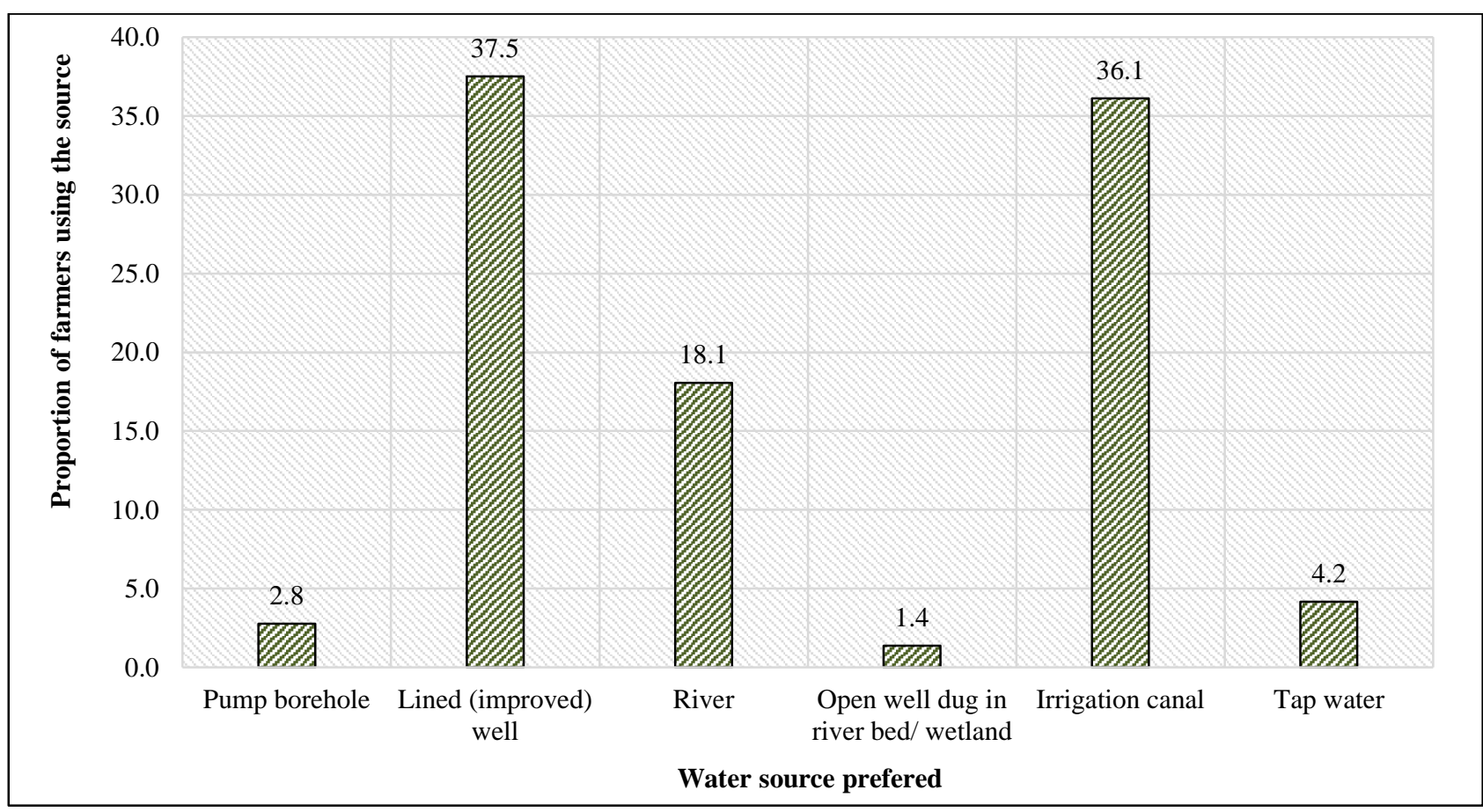

Figure 5. Preference of different water source at the community level

Slightly above a third of the household that preferred to draw their water from irrigation canal said it was less salty and closer to them. The problem is that the turbidity is much higher than the improved well. Its only problem was a higher turbidity. High turbidity issue was solved by use of a coagulant (Alum) as stratified by (16.7\%) of interviewers. Common alum is hydrated potassium aluminium sulphate $\mathrm{KAl}\left(\mathrm{SO}_{4}\right)_{2} \cdot 12 \mathrm{H}_{2} \mathrm{O}$ [44], which allows the suspended particles to settle down leaving the water clean and clear. Water from irrigation canal could be polluted by agrochemical which difficult to remove rendering it unsafe for consumption and use by residents.

\subsection{Type of Water Treatment used by the Community}

The study also focused on type of treatments the local community uses for their drinking water and presented in Figure 6 . The study established that almost half $(45.8 \%)$ of the people are chlorinating their water, $22.2 \%$ do nothing to their water for drinking, $16.7 \%$ uses coagulant, $12.5 \%$ filters with a cloth and only $2.8 \%$ boil their water before drinking.

The household that uses alum (16.7\%) for their drinking water treatment was perceived to obtain their water from either irrigation canal or river where the water turbidity is high. While those who do not use any water treatment was 
perceived to obtain their water from lined improved well, pump borehole or tap water due to low turbidity of the water. Belay et al. (2016) [45] in their study reported more than half 213(59.7\%) boil water, 74(20.7\%) settle and stand and 70(19.6\%) used chlorine in Burie Zuria Woreda Rural Households, Northwest Ethiopia. The types of treatment methods that the households reportedly used to treat water were boiling, bleach, filter, SODIS, let the water stand and settle, cloth straining, and other methods with the respective percentages of 10.81, 8.64, 0.79, 0.07, 1.25, 1.69, and $1.82 \%$ in Burundi, Lesotho, Namibia, Nigeria, Tanzania, Togo, and Uganda [46]. The revealed that majority of the people understand the importance of treating water, however the water can be contaminated with inorganic and organic pollutants such as herbicides and cannot be easily removed by conventional water treatment option making the resident vulnerable to diseases

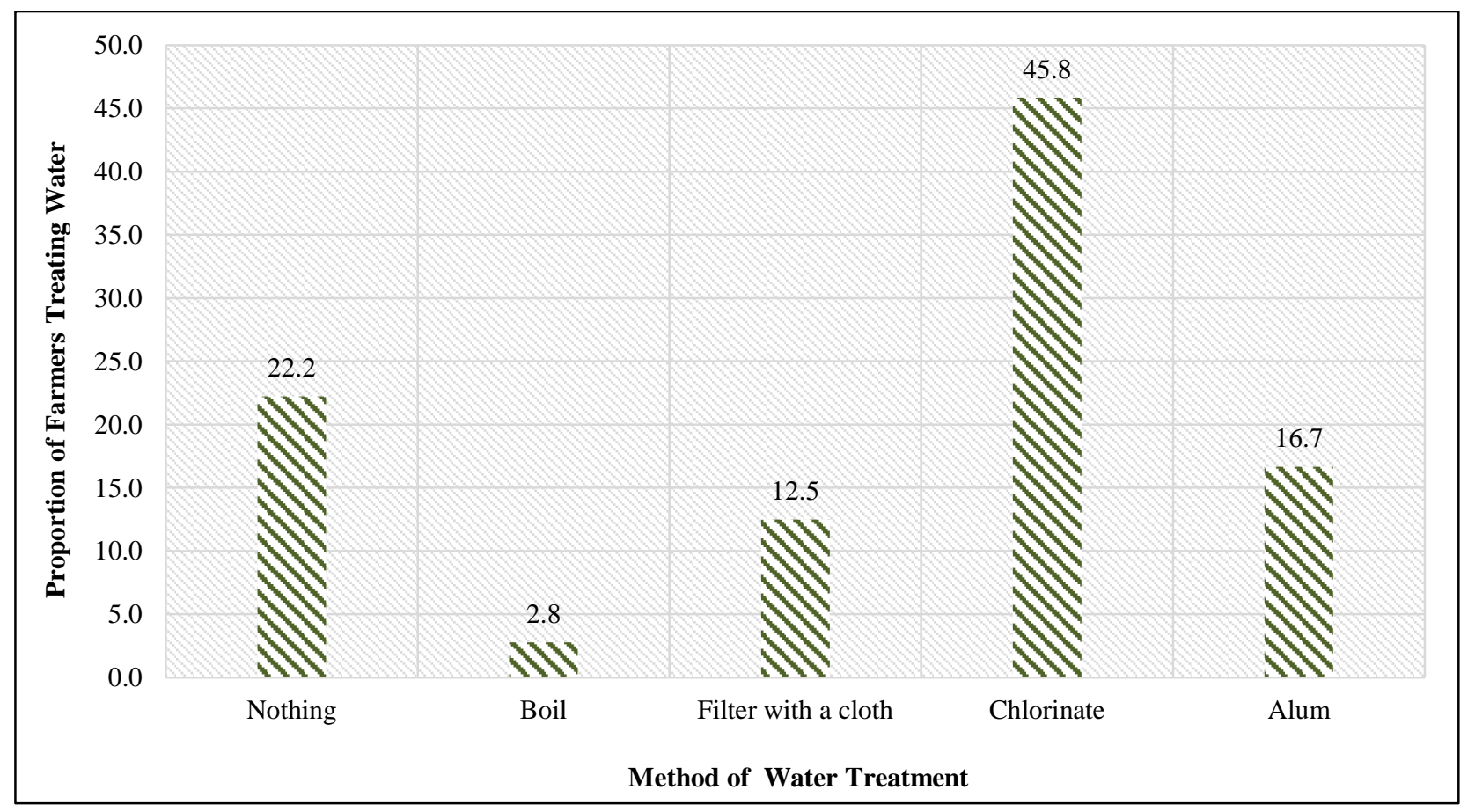

Figure 6. Proportion of different method of water treatment used by the farmers used in AIS

\subsection{Relationship between Water Source and the Type of Water Treatment}

The source of water was perceived to influence the type of water treatment and Spearman's coefficient of correlation was used to establish any relationships and the results are given in Table 4 . It shows that $13.9 \%$ of the people who obtain water from lined improved well do not treat their water, $4.2 \%$ filter their water with cloth and $25 \%$ chlorinate their water. Spearman's coefficient of correlation $\left(r_{s}\right)$ revealed that there was positive correlation between the two variables $\left(\mathrm{r}_{\mathrm{s}}=0.145, \mathrm{n}=72, \mathrm{p}=0.224>0.05\right)$. As $r_{s}$ is positive, it implies that the type of treatment given to water depend from it source of the water.

Table 4. Cross-tabulation of water source and method of drinking water treatment

\begin{tabular}{|c|c|c|c|c|c|c|c|}
\hline \multirow{2}{*}{ Water source } & \multicolumn{7}{|c|}{ Method of treatment of drinking water used } \\
\hline & & Nothing & Boil & Filter with Cloth & Chlorinate & Alum & Tota \\
\hline Pump borehole & $\%$ & - & 1.4 & - & 1.4 & - & 2.8 \\
\hline Lined(improved) well & $\%$ & 13.9 & 1.4 & 4.2 & 25 & 2.8 & 47.2 \\
\hline River & $\%$ & - & - & 5.6 & 5.6 & 5.6 & 16.7 \\
\hline Open well dug in river bed/ wetland & $\%$ & - & - & - & 4.2 & - & 4.2 \\
\hline Irrigation canal & $\%$ & 4.2 & - & 2.8 & 6.9 & 8.3 & 22.2 \\
\hline Tap water & $\%$ & 4.2 & - & - & - & - & 4.2 \\
\hline Rain water reservoir & $\%$ & - & - & - & 2.8 & - & 2.8 \\
\hline \multirow[t]{2}{*}{ Total } & $\%$ & 22.2 & 2.8 & 12.5 & 45.8 & 16.7 & 100 \\
\hline & p-value & \multicolumn{3}{|c|}{ Asymp. Std. Error ${ }^{a}$} & Approx. $T^{b}$ & \multicolumn{2}{|c|}{ Approx. Sig ${ }^{\mathrm{c}}$} \\
\hline Spearman Correlation & 0.145 & \multicolumn{3}{|c|}{0.123} & 1.227 & \multicolumn{2}{|c|}{0.224} \\
\hline $\mathrm{N}$ of Valid Cases & 72 & \multicolumn{3}{|c|}{ - } & - & \multicolumn{2}{|c|}{-} \\
\hline
\end{tabular}

A: Not assuming the null hypothesis; b: using the asymptotic standard error assuming the null hypothesis; c: based on the normal approximation. 


\section{Conclusion and Recommendations}

The study established that (52.8\%) of the farmers used hand-weeding and 20.8\% of them used 2,4-D for weed control. The people living around the Ahero irrigation scheme draw their water from a lined improved well, the Nyando River, irrigation canal, pump borehole, and a rainwater reservoir. The most preferred water source for the villages is the line improved well. Due to the saltiness of water drawn from the well and the long distance to the source, some people draw their water from irrigation canals. Close to half the population of people around the scheme prefer to use chlorine as a method for water treatment. There is a positive correlation between water sources and the method of water treatment. The following recommendations were made; finding and using substitute chemical for pest and weed control which is easily degradable and have less environmental and human impacts should be encouraged. Also adaptation of improved bio-sand filters as a small-scale purification process. For people who use the raw water from rivers and irrigation canals for drinking and cooking purposes. The improved Bio-Sand filter reduces the amount of organic contaminants such as pesticides, removes harmful micro-organisms that could be present in the water and reduces water turbidity, making it clean and safe for consumption. Further studies need to be done on the epidemiological studies on the association between 2,4-D and its degradation products used as an agrochemical and their health-related issues and also the amount that could be found in the environment. The findings can be used by the ministry of health or public health to sensitize the community on the safe measures of the use of agro-chemicals in order to alleviate the risks and carry out water quality analysis to validate the levels of 2,4-D in the irrigation schemes. Finally, further research can be done on the removal of other types of pesticide contaminants where other people practice different types of agriculture.

\section{Declarations}

\subsection{Data Availability Statement}

The data presented in this study are available in article.

\subsection{Funding}

The author received no financial support for the research, authorship, and/or publication of this article.

\subsection{Institutional Review Board Statement}

Not applicable.

\subsection{Informed Consent Statement}

Not applicable.

\subsection{Declaration of Competing Interest}

The author declare that there is no conflict of interests regarding the publication of this manuscript. In addition, the ethical issues, including plagiarism, informed consent, misconduct, data fabrication and/or falsification, double publication and/or submission, and redundancies have been completely observed by the author.

\section{References}

[1] Raji, M. I. O., \& Ibrahim, Y. K. E. (2011). Prevalence of waterborne infections in Northwest Nigeria: A retrospective study. Journal of Public Health and Epidemiology, 3(8), 382-385.

[2] Postel, S., \& Richter, B. (2012). Rivers for life: managing water for people and nature. Island Press, Washington, D.C., United States.

[3] Howard, G., Bartram, J., Water, S., \& World Health Organization. (2003). Domestic water quantity, service level and health (No. WHO/SDE/WSH/03.02). World Health Organization. Available online: https://apps.who.int/iris/handle/10665/67884 (accessed on January 2020).

[4] MacDonald, A. M., \& Calow, R. C. (2009). Developing groundwater for secure rural water supplies in Africa. Desalination, 248(1-3), 546-556. doi:10.1016/j.desal.2008.05.100.

[5] World Health Organization. (2019). Safer water, better health. Available online: https://apps.who.int/iris/bitstream/handle /10665/329905/9789241516891-eng.pdf (accessed on January 2020).

[6] Li, P., Tian, R., Xue, C., \& Wu, J. (2017). Progress, opportunities, and key fields for groundwater quality research under the impacts of human activities in China with a special focus on western China. Environmental Science and Pollution Research, 24(15), 13224-13234. doi:10.1007/s11356-017-8753-7. 
[7] Hiscock, K. M., \& Grischek, T. (2002). Attenuation of groundwater pollution by bank filtration. Journal of Hydrology, 266(34), 139-144. doi:10.1016/s0022-1694(02)00158-0.

[8] Agrawal, A., Pandey, R. S., \& Sharma, B. (2010). Water Pollution with Special Reference to Pesticide Contamination in India. Journal of Water Resource and Protection, 02(05), 432-448. doi:10.4236/jwarp.2010.25050.

[9] Edwards, C. A. (2013). Environmental pollution by pesticides (Vol. 3). Springer Science \& Business Media, New York, United States. doi:10.1007/978-1-4615-8942-6.

[10] Dhananjayan, V., \& Ravichandran, B. (2013). Organochlorine Pesticide Residues in Foodstuffs, Fish, Wildlife, and Human Tissues from India: Historical Trend and Contamination Status. Environmental Deterioration and Human Health, $229-262$. doi:10.1007/978-94-007-7890-0_10.

[11] Briassoulis, D., Hiskakis, M., Karasali, H., \& Briassoulis, C. (2014). Design of a European agrochemical plastic packaging waste management scheme-Pilot implementation in Greece. Resources, Conservation and Recycling, 87, 72-88. doi:10.1016/j.resconrec.2014.03.013.

[12] Uzogara, S. G. (2000). The impact of genetic modification of human foods in the 21st century: A review. Biotechnology advances, 18(3), 179-206. doi:10.1016/s0734-9750(00)00033-1.

[13] Pazmiño, D. M., Romero-Puertas, M. C., \& Sandalio, L. M. (2012). Insights into the toxicity mechanism of and cell response to the herbicide 2,4-D in plants. Plant Signaling \& Behavior, 7(3), 425-427. doi:10.4161/psb.19124.

[14] Garabrant, D. H., \& Philbert, M. A. (2002). Review of 2,4-Dichlorophenoxyacetic Acid (2,4-D) Epidemiology and Toxicology. Critical Reviews in Toxicology, 32(4), 233-257. doi:10.1080/20024091064237.

[15] Kurtoğlu, A. E., \& Atun, G. (2016). Competitive adsorption of 2,4-dichlorophenoxyacetic acid herbicide and humic acid onto activated carbon for agricultural water management. Desalination and Water Treatment, 57(53), 25653-25666. doi:10.1080/19443994.2016.1156027.

[16] Peterson, M. A., McMaster, S. A., Riechers, D. E., Skelton, J., \& Stahlman, P. W. (2016). 2,4-D Past, Present, and Future: A Review. Weed Technology, 30(2), 303-345. doi:10.1614/wt-d-15-00131.1.

[17] Zeljezic, D. (2004). Chromosomal aberrations, micronuclei and nuclear buds induced in human lymphocytes by 2,4dichlorophenoxyacetic acid pesticide formulation. Toxicology, 200(1), 39-47. doi:10.1016/j.tox.2004.03.002.

[18] Aksakal, O., Aygun Erturk, F., Sunar, S., Bozari, S., \& Agar, G. (2013). Assessment of genotoxic effects of 2,4dichlorophenoxyacetic acid on maize by using RAPD analysis. Industrial Crops and Products, 42, 552-557. doi:10.1016/j.indcrop.2012.06.038.

[19] Holland, J., \& Sinclair, P. (2003). Environmental fate of pesticides and the consequences for residues in food and drinking water. Pesticide residues in food and drinking water: Human exposure and risks, 27-62. doi:10.1002/0470091614.

[20] Borges, S., Dzubow, C., Orrick, G., Stavola, A., \& Branch, E. F. (2004). 2, 4-Dichlorophenoxyacetic Acid Analysis of Risks to Endangered and Threatened Salmon and Steelhead December 1, 2004.

[21] Damalas, C. A. (2014). Pesticide Drift: Seeking Reliable Environmental Indicators of Exposure Assessment. Environmental Indicators, 251-261. doi:10.1007/978-94-017-9499-2_15.

[22] Battaglin, W., \& Fairchild, J. (2002). Potential toxicity of pesticides measured in midwestern streams to aquatic organisms. Water Science and Technology, 45(9), 95-103. doi:10.2166/wst.2002.0213.

[23] Michałowicz, J., \& Duda, W. (2007). Phenols--Sources and Toxicity. Polish Journal of Environmental Studies, 16(3) 347-362.

[24] Bukowska, B. (2006). Toxicity of 2, 4-Dichlorophenoxyacetic Acid--Molecular Mechanisms. Polish Journal of Environmental Studies, 15(3), 365-374.

[25] Jaga, K., \& Dharmani, C. (2005). The Epidemiology of Pesticide Exposure and Cancer: A Review. Reviews on Environmental Health, 20(1), 15-38. doi:10.1515/reveh.2005.20.1.15.

[26] Kim, H.-J., Park, Y. I., \& Dong, M.-S. (2005). Effects of 2,4-D and DCP on the DHT-Induced Androgenic Action in Human Prostate Cancer Cells. Toxicological Sciences, 88(1), 52-59. doi:10.1093/toxsci/kfi287.

[27] Burns, C., Bodner, K., Swaen, G., Collins, J., Beard, K., \& Lee, M. (2011). Cancer Incidence of 2,4-D Production Workers. International Journal of Environmental Research and Public Health, 8(9), 3579-3590. doi:10.3390/ijerph8093579.

[28] Wilson, C., \& Tisdell, C. (2001). Why farmers continue to use pesticides despite environmental, health and sustainability costs. Ecological Economics, 39(3), 449-462. doi:10.1016/s0921-8009(01)00238-5.

[29] Pimentel, D., \& Burgess, M. (2014). Environmental and Economic Costs of the Application of Pesticides Primarily in the United States. Integrated Pest Management, 47-71. doi:10.1007/978-94-007-7796-5_2 
[30] Mburu c., Kinyua R., Karani G., Kiiyukia C. (2018) Occupational Safety and health Hazards exposure among Farm Workers at Ahero irrigation Scheme, Kenya. EPH-International Journal of Agriculture and Environmental Research 4(9):01-13.

[31] Too, G., Kollongei, J. K., Onyando, J. O., \& Mulindi, S. A. (2020). Analysis of Water Use in Rice Production under Paddy System and SRI in Ahero Irrigation Scheme, Kenya. Africa Environmental Review Journal, 3(2), 190-198.

[32] Omondi, S. O., \& Shikuku, K. M. (2013). An analysis of technical efficiency of rice farmers in Ahero Irrigation Scheme, Kenya. Journal of Economics and Sustainable Development, 4(10), 9-16.

[33] Omondi, S. O. (2014). Economic valuation of irrigation water in Ahero irrigation scheme in Nyando District, Kenya, Doctoral dissertation, University Of Nairobi, Nairobi, Kenya.

[34] Kothari, C. R. (2009). Research Methodology Methods and Techniques 2nd Revised edition. New Age International Publishers. New Delhi, India.

[35] Oyange, W. A., Chemining'wa, G. N., Kanya, J. I., \& Njiruh, N. P. (2019). Azolla Fern in MWEA Irrigation Scheme and Its Potential Nitrogen Contribution in Paddy Rice Production.

[36] Mattah, M. M., Mattah, P. A. D., \& Futagbi, G. (2015). Pesticide Application among Farmers in the Catchment of Ashaiman Irrigation Scheme of Ghana: Health Implications. Journal of Environmental and Public Health, 2015, 1-7. doi:10.1155/2015/547272

[37] Kim, K.-H., Kabir, E., \& Jahan, S. A. (2017). Exposure to pesticides and the associated human health effects. Science of the Total Environment, 575, 525-535. doi:10.1016/j.scitotenv.2016.09.009

[38] Alavanja, M. C. R., Ross, M. K., \& Bonner, M. R. (2013). Increased cancer burden among pesticide applicators and others due to pesticide exposure. CA: A Cancer Journal for Clinicians, 63(2), 120-142. doi:10.3322/caac.21170.

[39] Antoniou M, Habib M, Howard C, Jennings R, Leifert C, Nodari R, Robinson C, Fagan J: Teratogenic (2012) Effects of Glyphosate-Based Herbicides: Divergence of Regulatory Decisions from Scientific Evidence. Journal of Environmental \& Analytical Toxicology, 01(S4). doi:10.4172/2161-0525.s4-006.

[40] Kanoti, J. R., Olago, D., Opiyo, N., \& Nyamai, C. (2019). An overview of groundwater and sanitation challenges in Kisumu City, Kenya. Available online: http://erepository.uonbi.ac.ke/handle/11295/106934 (accessed on February 2020).

[41] Alekal, P. Y. (2005). Appropriate water treatment for the Nyanza Province of Kenya. Doctoral dissertation, Massachusetts Institute of Technology, Massachusetts, United States.

[42] Wagah, G. G., Onyango, G. M., \& Kibwage, J. K. (2010). Accessibility of water services in Kisumu municipality, Kenya. Journal of Geography and Regional Planning, 2, 114-125.

[43] Wambu, E. W., Agong, S. G., Anyango, B., Akuno, W., \& Akenga, T. (2014). High fluoride water in Bondo-Rarieda area of Siaya County, Kenya: a hydro-geological implication on public health in the Lake Victoria Basin. BMC Public Health, 14(1). doi:10.1186/1471-2458-14-462.

[44] Govindaraj, V., Murugan, P. R., Sankaran, S., Suthanthiram, S. S., Thirumurugan, J. M., Ismail, M. S. M., \& Senthilkumar, A. Augmenting Cleansing Process for Reducing Occupational Hazards Experienced by Labours Handling Pyrotechnical Chemicals in Firecracker Units. Special Issue, 9(2S2), 921-925. doi:10.35940/ijitee.b1150.1292s219.

[45] Belay, H., Dagnew, Z., \& Abebe, N. (2016). Small scale water treatment practice and associated factors at Burie Zuria Woreda Rural Households, Northwest Ethiopia, 2015: cross sectional study. BMC Public Health, 16(887), 1-8. doi:10.1186/s12889016-3571-2.

[46] Geremew, A., \& Damtew, Y. T. (2019). Household water treatment using adequate methods in sub-Saharan countries: evidence from 2013-2016 Demographic and Health Surveys. Journal of Water, Sanitation and Hygiene for Development, 10(1), 66-75. doi:10.2166/washdev.2019.107. 